in which every chemical or metallurgical operation required can be carried out.

Since it is expected that plutonium will be used to fuel future reactor systems, the study of the detailed chemistry and metallurgy of plutonium, its compounds and alloys is very important from a technological point of view; in addition, more basic studies of the chemistry of plutonium and other transuranic elements are carried out. Before leaving the laboratory, the Royal party were shown some of the results of research into methods for fabricating materials like uranium and thorium or beryllium and zirconium into forms which withstand the intense radiation conditions inside nuclear reactors. In particular, powder metallurgical methods have proved to be extremely important in this field.

The Royal party were also shown some of the experimental work which is being done at the Establishment directed towards the ultimate use of controlled thermonuclear reactions as a source of power. It is hoped to summarize the essential problems in this very interesting work shortly in $\begin{array}{ll}\text { Nature. } & \text { A. H. S. MatTerson }\end{array}$

\title{
HOME UNIVERSITIES CONFERENCE
}

\section{Organization of Postgraduate Studies}

$\mathrm{T}$ HE subject for the second session of the Home Universities Conference held in London during December 14-15 was "Organization of Postgraduate Studies". Sir James Mountford, vice-chancellor of the University of Liverpool, gave the opening address and surveyed the problem with a light touch. His comment that in arts the Ph.D. student is a relatively rare bird foreshadowed a discussion that concerned in the main the problems of scientists. He feared that with much organization there was little or no room for the student with 'a private hunch' in science departments.

He was followed by Dr. D. A. Bell, Department of Electrical Engineering, University of Birmingham, who emphasized the value of the M.Sc. degree by examination. Dr. Bell considers that while industry obviously needs the first-class man, it can also make use of the good honours man who has had postgraduate training. Dr. Bell also directed attention to the difficulties of organizing fundamental research in fields where research needs a staff of technicians as well as large and expensive apparatus.

Prof. F. S. Dainton, professor of physical chemistry, University of Leeds, showed an appreciation of the problem of selection of students for postgraduate research work, and felt that note should be taken of the quality of "persistence under adversity". He drew an interesting comparison between educational practice in universities in Britain and in the United States of America. He emphasized the value to the student of changing his university after his first degree, but made it clear that in the United States the interval between the first degree and the Ph.D. is sometimes four and often five years. Prof. Dainton doubted if the number of Ph.D. students should increase as rapidly as the number of those trained in directed research.

Prof. E. R. H. Jones, of the University of Oxford, welcomed the decision of the Department of Scientific and Industrial Research to give grants for students taking postgraduate diplomas. He thought that the training of postgraduate students in science should include training in methods of communicating results. Migration of senior postgraduate students from one university to another would be encouraged if there were more research awards for those who had already obtained the Ph.D. degree. He associated with this a plea that there be an increase in the number of postgraduate science students given permanent deferment from national service.

The discussion that followed emphasized the length of time needed to train the independent research worker. It was accepted that if notice was to be taken of the morning discussion, which had emphasized the overloading of the curricula of undergraduate studies, more would have to be done after the first degree. There was also considerable support for giving some training in the methods of research to those who might never become independent research workers.

Prof. J. G. Semple, of King's College, London, proposed a new 'Certificate of Advanced Studies'. Lord Chorley made it clear that the problem concerns law students as well as scientists, and that postgraduate training in law is increasingly demanded by the profession and by govermment departments.

\section{Technology and the Universities}

The third session of the Conference was devoted to the "Impact on the Universities of the Government's Policy for the Expansion of Technological Education". Three papers were presented and there was a lively discussion. Sir Eric Ashby, president and vice-chancellor of The Queen's University, Belfast, opened the session. He drew a parallel between the present upsurge of technological education and the upsurge of scientific education about a century ago. Competition from the proposed new colleges of technology, an increase in the prestige (and cost) of faculties of technology, and greater dependence on government finance - all these are problems for which there are precedents and for which it should not be difficult to devise solutions. But there remain two problems for which there are no precedents: one is the future faculties of arts, and the other is the place of humanities in faculties of technology.

These problems, though not new, now require solution urgently, for they are brought to a head by the expansion and encouragement of higher technological education. There are no precedents for them, because until recently the viability of faculties of arts was assured by the 'market-value' of arts degrees in the Civil Service and elsewhere; and technologists rarely attained positions of administrative responsibility, so that they were not obviously handicapped by their lack of any formal training in the humanities. The social climate has now entirely changed. In so far as faculties of arts pursue scholarship and train scholars, their place in universities is secure. But the greater part of their time is not spent on either of these activities, and it is their 'bread and butter lines' which need re-examination in the light of present Government policy. 
As to technologists, Sir Eric gave some evidence to indicate that more than a quarter of them end up in administration, for which some familiarity with arts subjects is quite essential. Technology is in any event inseparable from humanism, for it is the application of science to man and society. Sir Eric proposed two remedies: the first, that courses in such subjects as political institutions, economic history, social anthropology, and jurisprudence, should be obligatory ingredients of university courses in technology ; the second, that arts faculties should secure their viability by ensuring that their own graduates are familiar with the contemporary problems of civilization, and at the same time by providing essential courses for faculties of science and technology. This would involve raising the "ivory curtains between faculties".

Sir Harry Pilkington, chairman of the National Advisory Council for Industry and Commerce, emphasized that the responsibility of universities is to place technology in perspective as a servant of the community and not as a subject to be studied for its own sake. He would like to see the sharp division between science and arts at the universities deliberately blurred; he agreed with Sir Eric Ashby that university education should cut across faculties. Another important point made by Sir Harry Pilkington was that industry requires among its technologists not only specialists but also men with imaginative and creative casts of mind ; universities must produce the thinkers for industry. The very successes of industry in solving technological problems will give rise to new demands for non-material noeds, in literature and the arts, for example; and the country will look to the universities to satisfy these needs too. Finally, Sir Harry mentioned the impact on the universities of the inevitable improvement in the prestige of industrial work for graduates; as they come to realize that industry is neither dirty nor dull, some of the best scientists will certainly be attracted to industry away from universities.

The third paper was from Dr. Willis Jackson, of Metropolitan-Vickers Electrical Co., Ltd., who is chairman of the Joint Committee on the Supply and Training of Teachers for Technical Colleges. Dr. Jackson directed attention to a difficulty inherent in modern training in higher technology, namely, that technologists must, on one hand, become increasingly specialized and, on the other hand, must recognize the interdependence of different specialisms when technological problems have to be solved. In Dr.
Jackson's view, universities should concentrate their curricula upon basic science and interdepartmental activities, leaving it to industry to supply training in narrow specialist fields. One of the chief problems facing facultios of technology, Dr. Jackson said, will be the recruitment of staff; for an able young technologist wants to practise technology, not to teach it. This problem might be solved by two means: first, academic men should more commonly be appointed as consultants in industry, and from time to time should spend periods of full-time work in industry; secondly, universities should draw upon industry for visiting lecturers-not simply to give occasional lectures but to give complete and examinable courses to technology students. One obstacle to a closer integration between teaching and practice in technology is the fact that pension schemes are not ordinarily transferable between industry and universities; this obstacle should be removed.

During the discussion, Prof. J. Greig (King's College, London) asked universities to be prepared to recognize (with suitable safeguards) the new diploma in technology as a qualification allowing students to work for higher degrees. Mr. J. W. Gray (Queen's University, Belfast) challenged Sir Eric Ashby's suggestion that the contribution of arts faculties to faculties of technology should be confined to studies of contemporary society: it is often preferable to introduce students to unfamiliar civilizations. Prof. A. H. Naylor (Queen's University, Belfast) suggested that students with a better background in humane studies would be recruited into faculties of technology, if these faculties were prepared to forgo their special faculty requirements. Prof. A. F. Burstall (Newcastle upon Tyne) supported the plea for formal courses in the humanities for engineering students; and it was mentioned that the faculties of economics and law also have contributions to make to technological education. A very interesting contribution was made by Prof. J. J. Auchmuty, who is dean of the Faculty of Humanities in the New South Wales University of Technology. $\mathrm{He}$ is engaged in doing precisely what Sir Eric Ashby proposed should be done in British universities, for in the New South Wales University of Technology all students are obliged to study English, history and psychology. The chief difficulty, Prof. Auchmuty said, is to recruit suitable staff, and he considered that it will become necessary to institute a faculty of arts in the University of Technology in order to provide cohesion and stimulus for the humanities.

\title{
RADIO STAR SCINTILLATIONS AND INTERSTELLAR HYDROGEN
}

\author{
BY DR. G. A. HARROWER \\ Department of Physics, Queen's University, Kingston, Ontario
}

T is generally believed that the scintillation of a
radio star is the result of irregularities in the
density of ionization at a height of about $400 \mathrm{~km}$.
which move with a wind-like motion past the
observer's line of sight'. Two general questions
remain unanswered: the question of what agent or
agents may contribute to this ionization, and the
question of whether the ionization is produced in an
irregular pattern or becomes irregular after its pro- duction, perhaps due to turbulence. The work reported here was undertaken with the hope of obtaining at least a partial answer to the first of these questions.

At Ottawa during 1954, the radio signal from the strong source in Cassiopeia was recorded practically continuously at a frequency of $50 \mathrm{Mc} / \mathrm{s}$. The records were examined and judged to show scintillations, or not, for each hourly interval. The most prominent 